\title{
Inhibitors compounds of the flavivirus replication process
}

\author{
Leidy L. García*, Leonardo Padilla and Jhon C. Castaño
}

\begin{abstract}
Flaviviruses are small viruses with single-stranded RNA, which include the yellow fever virus, dengue virus, West Nile virus, Japanese encephalitis virus, tick-borne encephalitis virus, and Zika virus; and are causal agents of the most important emerging diseases that have no available treatment to date. In recent years, the strategy has focused on the development of replication inhibitors of these viruses designed to act mainly by affecting the activity of enzyme proteins, such as NS3 and NS5, which perform important functions in the viral replication process. This article describes the importance of flaviviruses and the development of molecules used as inhibitors of viral replication in this genus.
\end{abstract}

Keywords: Flavivirus, NS5 protein, Inhibitors

\section{Background}

Viruses of the Flaviviridae family are small enveloped viruses $(\sim 50 \mathrm{~nm})$ [1] with a single-stranded RNA genome of positive polarity. The complete genome is $9500-12,500$ nucleotides long and codes for a precursor polyprotein processed by viral and cellular proteases into structural proteins involved in capsid construction, as well as nonstructural proteins implicated in virus replication [2].

The flavivirus genus contains more than 53 members, including yellow fever virus (YFV), dengue (DENV), West Nile (WNV), Japanese encephalitis (JEV), tickborne encephalitis (TBEV) and Zika Virus (ZIKV) [3-7]. Members of this genus cause some of the most important diseases among emerging diseases; this is evident by an increased DENV prevalence in tropical and subtropical areas of the world, the emergence of WNV in North America, and the propagation of JEV in a large part of Asia and Oceania. Although authorized vaccines exist for yellow fever, Japanese encephalitis, and tick-borne encephalitis, these have had limited success in containing epidemics [8], while vaccines for other diseases caused by flaviviruses have yet to be developed [3]. Research on possible vaccine candidates for DENV, however, is currently being conducted; for example, in a recent phase III study, Villar et al., reported that a tetravalent vaccine (CYDTDV) for dengue that has been assessed in children from

\footnotetext{
* Correspondence: Ilgarciaa@uqvirtual.edu.co

Group of Molecular Immunology, Universidad del Quindío, Armenia (Quindío), Colombia
}

(c) The Author(s). 2017 Open Access This article is distributed under the terms of the Creative Commons Attribution 4.0 International License (http://creativecommons.org/licenses/by/4.0/), which permits unrestricted use, distribution, and reproduction in any medium, provided you give appropriate credit to the original author(s) and the source, provide a link to the Creative Commons license, and indicate if changes were made. The Creative Commons Public Domain Dedication waiver (http://creativecommons.org/publicdomain/zero/1.0/) applies to the data made available in this article, unless otherwise stated.

five countries in Latin America, where dengue is endemic, is efficient against virologically confirmed dengue (VCD) $[9,10]$, and after several decades of efforts, the first vaccine was recently licensed for use, but confers only partial cross protection for the four DENV serotypes [11].

The flavivirus genome contains an open reading frame, flanked by 5'- and 3'- untranslated regions that presents a secondary structure essential for translation and replication [3]. This polyprotein cleaves into ten proteins (three structural proteins: C (capsid), prM (membrane protein precursor), and $\mathrm{E}$ (envelope protein); and seven nonstructural proteins: NS1, NS2a, NS2b, NS3, NS4a, NS4b, and NS5) [1, 12].

To date, diverse inhibitor compounds of several flavivirus proteins have been evaluated, mainly from proteins with enzyme function, such as NS3 and NS5, and some molecules have been patented for this purpose, as well as to treat, prevent and alleviate infections caused by WNV, DENV and JEV $[13,14]$ On the other hand, peptides blocking virion envelope protein binding to host cell membranes have been designed [15], and sequences for protease substrates of DENV and WNV have been proposed [16].

In dengue, for example, the use of N-sulfonylanthranilic acid derivatives has been described in allosteric inhibition of the NS5 protein [17], while beta-d-2'-ethynyl-7-deazaadenosine triphosphate (2'E-7D-ATP) has been used in competition with the natural nucleotide [18]. Furthermore, compounds with no specific target have also been reported, which have been shown to affect the viral replication cycle, 
such as curcumin, a natural compound with several inhibitory effects in in vitro dengue type 2 virus-infected cells [19]. However, until now no antivirals compounds have been approved to treat diseases caused by flaviviruses [11].

This article highlights the main characteristics of flaviviruses, their importance in the search for inhibitor molecules, and the development of compounds that, to date, have been tested for the alteration of the replicative process of viruses of the genus.

\section{Viruses of the flavivirus genus}

The flavivirus genus contains several important human pathogens, including tick-borne encephalitis virus, Japanese encephalitis virus, West Nile virus, dengue virus, yellow fever virus and Zika virus [3, 4, 8, 20-25]. Most flaviviruses are transmitted to humans by arthropods; these types of viruses cause most of the emerging diseases. Currently, there are only three vaccines authorized against infections by flaviviruses: yellow fever virus, Japanese encephalitis virus, and tick-borne encephalitis virus $[3,8,21]$ Annually, nearly 400 million cases of dengue are reported worldwide [26]. In the Americas, approximately 150,000 suspected Zika cases have been reported and more than 3000 cases have been confirmed since March 2014 through May 2016 [27]. All flaviviruses are antigenically related, as shown in hemagglutination inhibition assays with polyclonal serum antibodies [22].

\section{Flavivirus genome}

Flaviviruses exhibit a spherical mature virion $500 \mathrm{~A}^{\circ}$ in diameter, the genome is packaged by a capsid protein (C) into a host-derived lipid bilayer with 180 copies of embedded envelope protein (E). The E protein forms a complex with the membrane protein precursor (prM) during virion assembly in the endoplasmic reticulum. It forms immature particles transported to the Golgi compartment, where a cellular serine protease matures them, furin, which mediates the cleavage of prM to $M$, resulting in the homodimerization of the $\mathrm{E}$ protein into mature fused competent particles before going into circulation. The flavivirus genome spans approximately $11 \mathrm{~Kb}$; it is composed of single-stranded positive-sense RNA and contains a single open-reading frame flanked by two 5'- and 3'- untranslated regions with secondary structures essential for translation and replication initiation $[1,3,21]$.

\section{Flavivirus polyprotein}

The virus enters the host cell through receptor-mediated endocytosis [28-31] and endosome acidification [32]. The flavivirus genome is released into the cytoplasm immediately after cell entry (including monocytes, macrophages, and dendritic cells) [3] by viral glycoproteinmediated membrane fusion [31]. The genome codes for a single polyprotein processed through proteolysis to produce three structural proteins: (E, prM, and $\mathrm{C}$ ) and seven nonstructural proteins: (NS) (NS1, NS2a, NS2b, NS3, NS4a, NS4b, and NS5) [3, 31, 33]. The polyprotein is co- and post-translationally cleaved by action of a combination of furin-type or other cellular proteases located in the Golgi compartment, as well as by the viral serine protease embedded in the $\mathrm{N}$-terminal domain of the NS3 protein (NS3 Pro), which requires NS2b for its activity [3]. It is possible that NS proteins undergo a cotranslational assembly in endoplasmic reticulum membranes, forming the competent replication complex, and later differ regarding the function and composition of nonstructural proteins [2].

\section{Flavivirus structural proteins}

The $\mathrm{C}$ protein, approximately $11 \mathrm{KDa}$, interacts with the viral genomic RNA, forming the nucleocapsid (NC), a functional region required for dimerization in viral assembly. The capsid protein contains an internal hydrophobic sequence that mediates membrane association [3].

The glycosylated prM, $26 \mathrm{KDa}$, is processed from the polyprotein in the endoplasmic reticulum by host signaling, through divisions in the $\mathrm{N}$-terminal site of the capsid-prM and prM C-terminal-E protein associations. The association of prM-E produces immature noninfectious viral particles; these immature particles travel through the Golgi apparatus and a reversible morphological change of the $\mathrm{E}$ protein is produced before $\mathrm{prM}$ processing $[3,22]$.

Cleavage of prM to $\mathrm{M}$ (membrane protein) by a cellular serine protease, furin, produces an irreversible conformational change in E. The peptide cleaved from prM is retained in the virion and released after the virion has segregated and is exposed to a neutral $\mathrm{pH}$, thus, protecting the $\mathrm{E}$ protein from premature fusion $[3,22]$.

The E protein, $53 \mathrm{KDa}$, in its dimer form, is the main component of the virion surface; in this form, the E protein is competent for cell surface binding, fusion, and viral entry into the host cells [3, 34]. The amino acid sequence identity of the $\mathrm{E}$ protein is at least 40 to $44 \%$ among flaviviruses [22].

\section{Flavivirus nonstructural proteins}

Nonstructural proteins are essential for virus replication, virion assembly, and invasion from the host's immune response; these are located mainly in the cytoplasm, forming replication complexes involved in viral RNA synthesis [35].

The NS1 protein has a molecular weight of 46-55 $\mathrm{KDa}$, depending on its state of glycosylation. It is present in multiple oligomeric forms, and is found in different cellular locations. Intracellular NS1 plays an essential role in virus replication and has proven to co-locate with 
dsRNA and other components of the replication complex; moreover, it can induce complement-mediated inhibition of the immune response and has the capacity to remodel membrane lipids [31]. Nonetheless, its precise protein function has not been elucidated, yet, it is known that the protein is highly immunogenic and can be proposed as the component of a new vaccine against flaviviruses [22, 36].

Regarding the NS2A protein, it has no enzymatic function, but it is necessary for virus replication and assembly [31, 35].

The NS2B protein is an integral membrane protein of $14 \mathrm{KDa}$ that contains three hydrophobic domains: two transmembrane segments located at the $\mathrm{N}$ - and $\mathrm{C}$ terminal ends and a central region of 47 amino acids (from residue 46 to 97), which acts as an essential cofactor for protein NS3) [3, 37].

NS2B binds to NS3 in the membrane, which is required for viral replication complex maturation [37].

The NS3 protein, $69 \mathrm{KDa}$, is the second longest viral protein in the flavivirus genome, after NS5, and plays an essential role in the viral replication cycle. NS3 contains a protease domain in the $\mathrm{N}$-terminal region that cleaves the viral protein precursor into individual NS proteins, and a C-terminal RNA helicase/NTPase domain, which participates in genome replication and viral RNA synthesis. In order to function as an active enzyme, the NS3 protease requires NS2B as a cofactor [31, 37].

The NS3 flavivirus protein is not soluble or catalytically active as an in vitro protease, suggesting that it does not fold properly without the NS2B protein. The helicase activity of NS3 is believed necessary for fusion of secondary structures before initiation of RNA synthesis or for the RNA duplex, whether to separate dsRNA compounds formed during viral RNA synthesis or as a translocase that can eliminate proteins bound to the viral RNA [37].

The NS4B protein (approximately $27 \mathrm{KDa}$ ) is an integral membrane protein with high hydrophobicity and moderate conservation with approximately $40 \%$ amino acid similarity among flaviviruses [35]. The NS4A protein induces membrane reordering and autophagy to improve viral replication, while NS4B modulates the host's immune response by suppressing interferon $\alpha / \beta$ signaling and NS3 helicase activity [31]. These two proteins do not show an identified enzymatic activity, but are believed to serve as essential scaffolds for viral replication complex formation, along with NS2A and NS2B [35, 38].

The NS5 protein (close to $100 \mathrm{KDa}$ ) is the biggest viral protein coded by flaviviruses and the most highly conserved $[2,5]$, with a shared sequence identity of over 75\% amongst all DENV serotypes [3]. The C-terminal domain structure of WNV and DENV NS5 proteins revealed that it is a classic polymerase [5]. NS5 is of great importance to viral replication, given that it performs two independent enzymatic activities separated by an interdomain region: an S-adenosyl methyltransferase (SAM) and an $\operatorname{RdRp}$ [3, 30, 39], essential activities for the viral replication cycle [40]. In addition, it codes the main type I interferon (IFN)-signaling antagonist [37, 41].

The RdRp of the NS5 protein initiates RNA synthesis through a de novo mechanism $[5,8]$ that differs from the primer-dependent mechanism used by other viruses. Like all polymerases, the structure of the flavivirus $R d R p$ is similar to a right hand with characteristic fingers, palm, and thumb subdomains $[5,42]$.

\section{Development of flavivirus inhibitors}

Identification of small molecules that inhibit a critical step in the viral cycle requires detailed biochemical and structural characterization of each protein essential for replication. The $\mathrm{C}$, prM, and $\mathrm{E}$ viral proteins undergo conformational changes during viral particle entry, assembly, and exit; these changes can be targets inhibited by antiviral drugs [3].

In the case of dengue, development of an antiviral drug is complicated due to the presence of four serotypes; thus, while lifelong protection against one serotype is induced, protection against the other serotypes lasts only a few months [22]. Incomplete protection against a serotype can affect the outcome of the disease upon establishing infection by a different serotype, through a process known as antibody-mediated disease improvement, immunopotentiation, or antibody-mediated immunofacilitation.

Continuous interest exists for vaccines and drugs effective against viruses, such as dengue and West Nile viruses, due to the difficulties seen with existing drugs, such as the reported controversial effect of ribavirin on flaviviruses [2]. Besides, the recent interest in the search for inhibitors has also increased, due to the recent epidemics caused by the Zika virus, thus this disease has become a public health problem [43].

\section{Compounds used as flavivirus inhibitors}

Diverse biological and synthetic compounds have been designed and evaluated in vitro and in vivo, including bioinformatics-based assays, seeking to induce inhibition of the most important protein activities in the viral replication process of this genus (see Table 1). Some of these compounds, however, have been tested with no specific target other than affecting viral particle replication. The compounds discussed ahead have been tested as flavivirus inhibitors and inhibitors of the viral cycle proteins of highest interest.

\section{Inhibitors of the $E$ protein}

In DENV, a few heterocyclic compounds, like NITD448, compound 6 (with a quinazoline nucleus) [38], P02, 
Table 1 Main compounds used as flavivirus inhibitors

\begin{tabular}{|c|c|c|c|}
\hline Protein & Compound & Flavivirus & References \\
\hline \multirow[t]{8}{*}{$\bar{E}$} & NITD-448 & DENV & Lim et al., 2013a [38] \\
\hline & Compound 6 & DENV & Lim et al., 2013a [38] \\
\hline & P02 & $\begin{array}{l}\text { DENV, } \\
\text { YFV }\end{array}$ & $\begin{array}{l}\text { Zhou et al., } 2008 \text { [44] } \\
\text { Lim et al., 2013a [38] }\end{array}$ \\
\hline & D02, D04 and D05 & DENV & Zhou et al.,2008 [44] \\
\hline & A5 & $\begin{array}{l}\text { DENV, } \\
\text { YFV, } \\
\text { WNV }\end{array}$ & Lim et al., 2013a [38] \\
\hline & 1662G07 & DENV & Lim et al., 2013a [38] \\
\hline & Castanosper-mine & DENV & Lim et al., 2013a [38] \\
\hline & Celgosivir & DENV & Lim et al., 2013a [38] \\
\hline
\end{tabular}

\begin{tabular}{|c|c|c|c|}
\hline & Peptide DN59 & DENV & $\begin{array}{l}\text { Lok et al., 2012; [46] } \\
\text { Badani et al., } 2014 \text { [45 }\end{array}$ \\
\hline C & ST-148 & DENV & Lim et al., 2013a [38] \\
\hline \multirow[t]{2}{*}{$\begin{array}{l}\text { NS3- } \\
\text { ProteasE }\end{array}$} & $\begin{array}{l}\text { Bowman-Birk } \\
\text { inhibitor }\end{array}$ & DENV & Bollati et al., 2010 \\
\hline & BP13944 & DENV & Yang et al.,2014 [48 \\
\hline
\end{tabular}

Compound 32 (keto amides)

Peptide WCW$\mathrm{NH} 2$

ARDP0006 and ARDP0009

Aprotinin

NS3HelicasE

$\begin{array}{lll}\begin{array}{l}\text { Halogenated } \\ \text { benztrioles } \\ \text { Ivermectin }\end{array} & \text { WNV } & \begin{array}{l}\text { Sampath and Padmanabhan } \\ 2009 \text { [3] }\end{array} \\ \text { ST-610 } & \begin{array}{l}\text { DENV, } \\ \text { JEV, YFV }\end{array} & \begin{array}{l}\text { Mastrangelo et al., 2012 [55]; } \\ \text { Sweeney et al., 2015 [57] }\end{array} \\ & \text { DENV } & \begin{array}{l}\text { Lim et al., 2013a [38]; Sweeney } \\ \text { et al., 2015 [57] }\end{array} \\ \text { Suramin } & \text { DENV } & \begin{array}{l}\text { Basavannacharya, Vasudeban, } \\ \text { 2014 [58]; Sweeney et al., 2015 } \\ \text { [57] }\end{array} \\ \text { Analogues ML283 } & \text { DENV } & \text { Sweeney et al., 2015 [57] }\end{array}$

Analogues ML283 DENV Sweeney et al., 2015 [57]
DENV

DENV

DENV

Tonlimson and Watowich, 2011 [51]

DENV

Noble et al., 2010 [53]

Pyrrolone
DENV,
WNV
State

NITD-448 inhibited E protein-mediated membrane fusión as well as DENV-2 infection. Due to the large molecular weight of this compound, por selectivity, and pharmacokinetic properties, this compound series was not further pursued.

Compound 6 has low potency and high plasma protein-binding activity due to lipophilicity that prevented further development of the compound.

P02 inhibits viral replication at micromolar concentrations. No follow-up studies have been reported for this compound.

D02, D04 and D05 inhibit the virus life cycle. This compounds reduced viral replication activity.

A5 has low micromolar activity against DENV, WNV, and YFV. No followup studies have been reported for this compound.

SAR studies led to analogs with activity against DENV-2, some activity against DENV-4, but weak activity against DENV-1 and -3 . The antiviral spectrum of this compound needs to be evaluated.

Castanospermine inhibit DENV replication, disrupting folding of DENV structural proteins prM and E, as well as NS1.

Celgosivir inhibit DENV replication, disrupting folding of DENV structural proteins prM and E, as well as NS1. A phase lb clinical trial is currently ongoing to evaluate the activity, pharmacokinetics, safety, and tolerability of Celgosivir in dengue patients.

Peptide DN59 inhibits the infectivity of flaviviruses by releasing their genome.

ST-148 has limited oral bioavailability. Greater preclinical development is warranted.

A starting point is provided for the design of specific inhibitors. The current situation of this compounds is unknown.

BP13944 inhibited viral replication or RNA synthesis in all four DENV serotypes. Further work is required to determine the interaction mechanism.

An inhibitory effect on DENV replication was determined in a dosedependent manner. Cytotoxicity in cell culture is unknown.

Peptide WCW-NH2 inhibited protease in the four serotypes.

ARDP0006 and ARDP0009 inhibited DENV-2 virus replication in cell culture. Promising compounds for future research.

Aprotinin envelops the enzyme and prevents the substrate from accessing the protease active site.

Halogenated benztrioles were good, and selective inhibitor of the West Nile virus.

Promising compound as the first specific therapy against flaviviruses (patent application EP2010/065880).

ST610 potently and selectively inhibited all four DENV serotypes in cell culture. For future trials, the pharmacokinetic properties of this compound should be improved.

Suramin acted as a potent NS3 helicase inhibitor of dengue virus by a non-competitive mode of inhibition.

Analogues ML28331 were potent inhibitors of DENV NS3- catalyzed ATP hydrolysis. These trials serve as a tool to find more inhibitory compounds.

Pyrrolone inhibited DENV replicon and WNV replication in cell culture. These trials serve as a tool to find more inhibitory compounds. 
Table 1 Main compounds used as flavivirus inhibitors (Continued)

\begin{tabular}{|c|c|c|c|}
\hline \multirow[t]{2}{*}{ NS4 B } & SDM25N & DENV & Van Cleef et al., 2013 [59] \\
\hline & NITD-618 & $\begin{array}{l}\text { DENV, } \\
\text { WNV, } \\
\text { YFV }\end{array}$ & $\begin{array}{l}\text { Van Cleef et al., } 2013 \text { [59]; Lim } \\
\text { et al., 2013a [38] }\end{array}$ \\
\hline \multirow{9}{*}{$\begin{array}{l}\text { NS5- } \\
\text { metHYl- } \\
\text { transfe-rasE }\end{array}$} & Sinefungin & $\begin{array}{l}\text { DENV, } \\
\text { WNV }\end{array}$ & Lim et al., 2015 [61] \\
\hline & $\begin{array}{l}\text { S-adenosyl } \\
\text { homocysteine }\end{array}$ & DENV & Lim et al., 2015 [61] \\
\hline & Compound 10 & DENV & $\begin{array}{l}\text { Lim et al., 2013a [38] } \\
\text { Lim et al., } 2015 \text { [61] }\end{array}$ \\
\hline & GMP & DENV & Lim et al.,2015 [61] \\
\hline & BG-323 & DENV & Lim et al., 2015 [61] \\
\hline & $\begin{array}{l}\text { Aurintricarboxylic } \\
\text { acid }\end{array}$ & $\begin{array}{l}\text { DENV, } \\
\text { YFV }\end{array}$ & Lim et al., 2015 [61] \\
\hline & $4-H P R$ & DENV & $\begin{array}{l}\text { Lim et al. } 2015 \text { [61]; } \\
\text { Lai et al., } 2017 \text { [10] }\end{array}$ \\
\hline & Ivermectin & DENV & $\begin{array}{l}\text { Lim et al., 2013a [38]; } \\
\text { Lim et al., } 2015 \text { [61]; } \\
\text { Lai et al., } 2017 \text { [10] }\end{array}$ \\
\hline & Ribavirin & DENV & Lim et al., 2013a [38] \\
\hline \multirow[t]{2}{*}{$\begin{array}{l}\text { NS5- } \\
\text { polYmera- } \\
\text { SE }\end{array}$} & $\begin{array}{l}\mathrm{N}-(4 \text { hydroxy- } \\
\text { phenyl) } \\
\text { retinamide }\end{array}$ & DENV & Lim et al., 2015 [61] \\
\hline & Ivermectin & DENV & $\begin{array}{l}\text { Tay et al., } 2013 \text { [56]; } \\
\text { Lim et al., } 2015 \text { [61] }\end{array}$ \\
\hline
\end{tabular}

SDM25N showed antiviral activity against wild-type DENV2 in both Hela and BHK-21 cells, but not in the C6/36 cell line. Further studies are required.

The high lipophilicity of NITD-618 resulted in poor pharmacokinetic properties which hindered testing its activity against DENV in AG129 mice. It was inactive against WNV and YFV.

The affinity for Sinefungin is approximately six times higher than for SAM. Sinefungin is non-cell permeable. This compound does not show progress

S-adenosyl homocysteine is non-cell permeable. This compound does not show progress.

Compound 10 is non-cell permeable. This compound does not show progress.

GMP is non-cell permeable. This compound does not show progress.

BG-323 showed in vitro inhibition of DENV. The current situation of this compound is unknown.

Aurintricarboxylic acid inhibited the DENV MTase and YFV. The current situation of this compound is unknown.

4-HPR showed efficacy in DENV mouse models. Promising compound. Due to its tolerable human profile, it could be a treatment for patients with DENV.

vermectin is a promising compound. The estimated study completion date was February 2016 (ClinicalTrials.gov identifier: NCT02045069).

Ribavirin has limited use due to its toxicity, thus, decreasing its clinical effectiveness.

$\mathrm{N}$-(4-hydroxyphenyl) retinamide did not affect NS5 RdRp activity, but inhibited DENV replication in cells.

Ivermectin did not affect NS5 RdRp activity, but inhibited DENV replication in cells. However, problems related to the toxicity of ivermectin may present significant challenges for its potential use in anti-DENV therapy.

7-deaza-2'-C

3'dGTP

DENV

Malet et al., 2008 [8]

ddGTP

DENV

Malet et al., 2008 [8]

3'dioxolano

DENV

Malet et al., 2008 [8]

3'dGTP

2'-O-metil GTP

DENV

Malet et al., 2008 [8]

HPA 23

DENV

Malet et al., 2008 [8]

NITD 008

DENV, Lim et al., 2013a [38];

WNV, $\quad$ Caillet et al., 2014 [30]

NITD 203 YFV

Calleit et al., 2014 [30]

WNV,

YFV

Balapiravir

DENV

Lim et al., 2015 [61]

N-sulfonylDENV

Niyomrattanakit et al., 2010 anthranilic acid [17]

7DMA was shown to reduce viremia and delay the time to disease progression in virus-infected mice.

3'dGTP showed low micromolar IC50 values in in vitro DENV2 RdRp activity tests using a poly $(\mathrm{r} C)$ template.

ddGTP showed low micromolar IC50 values in in vitro DENV2 RdRp activity tests using a poly $(\mathrm{r} C)$ template.

3'dioxolano 3'dGTP showed low micromolar IC50 values in in vitro DENV2 RdRp activity tests using a poly(rC) template.

2'-O-metil GTP showed low micromolar IC50 values in in vitro DENV2 $\mathrm{RdRp}$ activity tests using a poly(rC) template.

HPA 23 Inhibited virus replication in Vero cells. The current situation of this compound is unknown.

Severe side-effects were observed in rats and dogs. These results led to the termination of NITD-008 for further development for DENV treatment.

NITD 203 showed in vivo toxicity after 2 weeks of administration in rats and dogs.

Balapiravir failed to be effective for patients with DENV. No efficacy was found in phase II Clinical trial.

NITD-29 inhibited DENV-2 in a virus titer reduction assay, neither NITD-1 nor NITD-2 exhibited any antiviral activity in cell culture. 
Table 1 Main compounds used as flavivirus inhibitors (Continued)

\begin{tabular}{|c|c|c|c|c|}
\hline & 2'E-7D-ATP & DENV & $\begin{array}{l}\text { Latour et al., } 2010 \text { [18]; } \\
\text { De Burghgraeve et al. } 2013 \\
\text { [64] }\end{array}$ & $\begin{array}{l}\text { 2'E-7D-ATP was able to inhibit all DENV serotype replication. However, } \\
\text { the catalytic efficiency of incorporating this molecule was } 10 \text {-fold lower } \\
\text { than that of ATP. }\end{array}$ \\
\hline & $\begin{array}{l}\text { Modified tri- } \\
\text { phenylmethyl } \\
\text { nucleosides }\end{array}$ & $\begin{array}{l}\text { DENV, } \\
\text { YFV }\end{array}$ & Chatelain et al., 2013 [23] & $\begin{array}{l}\text { The finding of these lipophilic structures should stimulate the interest } \\
\text { for further structure activity research. }\end{array}$ \\
\hline & $\begin{array}{l}\text { 2, } 5^{\prime} \text {-bis-O- } \\
\text { tritylated uridine }\end{array}$ & $\begin{array}{l}\text { DENV, } \\
\text { YFV }\end{array}$ & Chatelain et al., 2013 [23] & $\begin{array}{l}\text { 2,5'-bis-O-tritylated uridine proved to be successful. This discovery was } \\
\text { followed by synthesis of a series of close analogues, as a first attempt } \\
\text { for setting up a structure activity relationship (SAR). }\end{array}$ \\
\hline & $\begin{array}{l}\text { 3', } 5^{\prime} \text {-bis-O- } \\
\text { tritylated uridine } \\
\text { analogues }\end{array}$ & $\begin{array}{l}\text { DENV, } \\
\text { YFV }\end{array}$ & $\begin{array}{l}\text { Chatelain et al., } 2013 \text { [23]; } \\
\text { Saudi et al., 2014a [25] }\end{array}$ & $\begin{array}{l}\text { These simple lipophilic structures show strong YFV inhibiting properties, } \\
\text { further structure activity research is warranted. }\end{array}$ \\
\hline & $\begin{array}{l}\text { Compound 27, 29i } \\
\text { and } 29\end{array}$ & DENV & Lim et al., 2016 [11] & $\begin{array}{l}\text { Compound } 27 \text { inhibted all four serotypes when inhibition studies were } \\
\text { performed with clinical isolates of DENV1-4. Compound } 29 \text { i was the } \\
\text { next most potent compound and } 29 \text { displayed relatively lower cellular } \\
\text { inhibition. }\end{array}$ \\
\hline $\begin{array}{l}\text { no } \\
\text { speCIFIC } \\
\text { ACTION }\end{array}$ & Lycorine & $\begin{array}{l}\text { WNV, } \\
\text { YFV, } \\
\text { DENV }\end{array}$ & $\begin{array}{l}\text { Zou et al., } 2009 \text { [21]; Lim et al., } \\
\text { 2013a [38]; }\end{array}$ & $\begin{array}{l}\text { Lycorine potently inhibited flaviviruses in cell culture, it was reported to } \\
\text { reduce viral titers of WNV, DENV, and YFV mainly through suppression } \\
\text { of viral RNA replication. }\end{array}$ \\
\hline & Amodiaquine & DENV & $\begin{array}{l}\text { Boonyasuppayakorn et al., } \\
2014 \text { [33] }\end{array}$ & Amodiaquine inhibited DENV2 infectivity measured by plaque assay. \\
\hline & AS101 & WNV & Indenbaum et al., 2012 [69] & $\begin{array}{l}\text { AS101 had a potential preventive and therapeutic effect against WNV } \\
\text { infection. }\end{array}$ \\
\hline & $\begin{array}{l}\text { 7-deaza-2'-C- } \\
\text { acetylene- } \\
\text { adenosine }\end{array}$ & DENV & $\begin{array}{l}\text { De Burghgraeve et al., } 2013 \\
\text { [64] }\end{array}$ & $\begin{array}{l}\text { 7-deaza-2'-C-acetylene-adenosine showed anti-DENV activity in cell cul- } \\
\text { ture and significantly reduced viremia in a mouse model. }\end{array}$ \\
\hline & I45DC & $\begin{array}{l}\text { DENV, } \\
\text { YFV }\end{array}$ & Saudi et al., 2014b [70] & 145DC had a high dengue virus inhibitory activity. \\
\hline & $\begin{array}{l}\text { P23DCs } \\
\text { derivatives }\end{array}$ & $\begin{array}{l}\text { DENV, } \\
\text { YFV }\end{array}$ & Saudi et al., 2014b [70] & P23DCs derivatives had potent DENV and YFV inhibitory properties. \\
\hline & $\begin{array}{l}\text { Favipiravir } \\
\text { (T-705) }\end{array}$ & $\begin{array}{l}\text { FYV } \\
\text { WNV }\end{array}$ & $\begin{array}{l}\text { De Burghgraeve et al., } 2013 \\
\text { [64]; } \\
\text { Furuta et al., } 2013 \text { [71] }\end{array}$ & $\begin{array}{l}\text { Lack of good in vitro antiviral activity of Favipiravir (T-705). Considerably } \\
\text { higher concentrations of this compound were required. }\end{array}$ \\
\hline & $\begin{array}{l}\text { T-1105 and } \\
\text { T-1106 }\end{array}$ & $\begin{array}{l}\text { FYV } \\
\text { WNV }\end{array}$ & Furuta et al., 2009 [72] & $\begin{array}{l}\text { There are insufficient data to clarify the reason why the in vivo antiviral } \\
\text { effect of T-1106 did not correspond to its in vitro activity and why there } \\
\text { were such differences in antiviral activities between T-1106 and T-705. } \\
\text { T-1106 can be a useful drug for YFV in humans. }\end{array}$ \\
\hline & NITD008 & ZIKV & $\begin{array}{l}\text { Deng et al., } 2016 \text { [73]; } \\
\text { Xie et al., } 2016 \text { [43]; } \\
\text { Adcock et al., } 2017 \text { [27] }\end{array}$ & $\begin{array}{l}\text { NITD008 showed potent anti-ZIKV activity. It could serve as a reference } \\
\text { inhibitor for future drug screen and discovery. }\end{array}$ \\
\hline & $\begin{array}{l}\text { ZINC33683341 } \\
\text { and } \\
\text { ZINC49605556 }\end{array}$ & ZIKV & Sandun et al., 2016 [74] & $\begin{array}{l}\text { The results obtained from these assays are a starting point for drug } \\
\text { discovery targeting Zika virus and other emerging pathogens. }\end{array}$ \\
\hline
\end{tabular}

D02, D04, D05, A5, and 1662G07 have been identified in silico. Some of these (for example, NITD-448) inhibit E protein-mediated membrane fusion, such as DENV-2 infection in cell culture. P02 inhibits viral replication at micromolar concentrations; as a result, it is considered a promising compound for future development of an effective treatment against dengue virus and related flaviviruses [44]. NITD refers to compounds developed by the Novartis Institute for Tropical Diseases, whose mission is to develop drugs against dengue [38].

Other compounds, like compound 6, present inhibition in clinical DENV isolates. D02, D04 and D05 inhibit the virus life cycle at steps other than replication, consistent with inhibition of maturation or virus entry into cells as a result of binding E protein. Further, P02 showed inhibition of YFV, and A5 against WNV, DENV, and YFV [38].

Moreover, various studies have shown that castanospermine and celgosivir also inhibit dengue virus replication, interrupting E protein folding, as well as prM and NS1 folding [38].

Reports indicate that the mimetic peptide DN59 [45], which matches with a region of the dengue virus envelope protein, inhibits the four dengue virus serotypes, as well as other flaviviruses. This compound strongly interacts with synthetic lipid vesicles and causes membrane alterations; 
yet, it was not toxic to mammal and insect cells. As a result, DN59 inhibits flavivirus infection through direct interaction with viral particles, resulting in genomic RNA release [46].

\section{Capsid inhibitors}

Compound ST-148 is a DENV capsid inhibitor; this compound inhibits DENV with a titer reduction at EC50 of $0.016 \mu \mathrm{M}[38]$ in addition to blocking the cytopathic effect caused by DENV. This compound is potent against the four dengue virus serotypes, as well as against other flaviviruses; its inhibitor effect was evaluated in in vitro and in vivo assays in mice (AG129), revealing that it significantly reduces viremia and viral loads in vital organs [47].

\section{NS3 protein inhibitors}

Considering that the NS3 protein performs various important processes in viral replication, diverse inhibitors have been designed against its protease and helicase activities; thus, it is a promising protein for vaccine and treatment development for flavivirus diseases.

\section{Protease domain inhibitors}

Diverse inhibitors of the flavivirus protease domain have been evaluated; for example, NS3 has been proposed to interact with the Bowman-Birk-type polypeptide inhibitor, isolated from mung beans, and represents the only structure of a DENV2 NS3 complex available to date. This bivalent inhibitor contains a lysine and arginine occupying the substrate-binding S1 pocket; therefore, it affects NS3 binding to NS2B by binding to this pocket [2].

The flexible behavior of the DENV NS3 protease, as seen through computational tools, is not observed with three ligand complexes of WNV, all containing the NS2B cofactor. One of them harbors aprotinin as an inhibitor ligand, while the other two form a complex with an analogous peptide-type substrate covalently bound to a residue of the catalytic triad Ser135. Aprotinin shows the highest specificity to the NS3 protease pocket [2].

Compound BP13944, a quaternary ammonium salt, is identified as a dengue protease inhibitor, through highthroughput screening (HTS) of 60,000 chemical compounds, using a BHK-21 (Baby Hamster Kidney fibroblasts) stable cell line containing an efficient DENV-2 luciferase replicon. BP13944 reduced DENV reporter replicon expression in cells, showing a half-maximal effective concentration (EC50) of $1.03 \pm 0.09 \mu \mathrm{M}$. With no detectable toxicity, the compound inhibits viral RNA replication or synthesis in all dengue serotypes, although not in the JEV [48].

Additionally, keto amides have been evaluated as dengue virus protease inhibitors in cell culture, with reports that compound 32 inhibits replication in a dose-dependent fashion, reducing viral titers 1000 -fold to non-cytotoxic concentrations, determined through luciferase measurement as a cell viability marker [49].

A set of 45 inhibitor peptides was designed, synthesized, and evaluated against the dengue virus NS2B-NS3 protease, finding that the uncharged WCW-NH2 tetrapeptide inhibits protease in the four serotypes [50].

Furthermore, anthracene-based compounds, ARDP0006 and ARDP0009, have been identified through virtual screening of a chemical compounds library by identifying small molecules that fit in defined target sites, such as the active site and P1 pocket of the DENV protease, finding that these compounds inhibit dengue-2 virus replication in cell culture [51]. ARDP0006 (anthraquinone) was the most potent inhibitor among all others evaluated, which reduced viral titers more than $1 \log \mathrm{PFU} / \mathrm{mL}$ in $\mathrm{HuH}-7$ and K562 cell lines [52].

Currently, few compounds show adequate properties for drug development, which may be attributed to the fact that inhibitors weakly bind to the enzyme, given that classic serine-protease inhibitors are inefficient or have a low potential against the DENV NS3 protease. One exception, though, is aprotinin, which envelops the enzyme and keeps the substrate from accessing the protease active site [53].

\section{Helicase domain inhibitors}

The crystalline structure of the DENV NS3 helicase domain reveals that this domain does not contain any pockets for possible binding to small inhibitor molecules [53, 54].

Despite scarce reports of NS3 helicase inhibitors, to date, the existence of halogenated benztrioles that inhibit the WNV helicase has been reported [3], and ivermectin, an antiparasitic drug against helminths, has been reported to display inhibition against the helicase activity of DENV, JEV and YFV [10, 55-57].

Recently, there have also been reports that ST-610 (discovered in assays monitoring the cytopathic effect of DENV) acts as a helicase inhibitor, selectively inhibiting the four DENV serotypes in cell culture, but it does not inhibit the ATPase activity $[38,57]$.

Moreover, suramin (a polysulfonated compound used as an antihelminthic) has been shown to act as a noncompetitive inhibitor of the DENV helicase; this compound was discovered for DENV inhibition through screening of a compound library using a molecular probebased helicase assay $[57,58]$.

Similarly, analogues of the ML283 compound (a benzothiazol oligomer derived from the primuline dye), which inhibit the hepatitis $\mathrm{C}$ virus ( $\mathrm{HCV}$ ) helicase, are active against DENV replicons, acting as potent inhibitors of NS3 through catalysis by ATP hydrolysis. In addition, pyrrolone specifically inhibits NS3 capacity to cleave ATP, as 
well as $50 \%$ of DENV and WNV (subtype Kunjin) replication in cells [57].

Finally, helicase inhibitors have been shown to serve as antiviral therapy against flaviviruses and this was recently reviewed [37, 38].

\section{NS4 protein inhibitors}

The NS4 protein, although not having a specific enzymatic activity, is also an important target against flaviviruses. Recently, a new dengue virus inhibitor against the NS4B viral protein was identified, which restricts genomic RNA replication instead of viral genome translation; nevertheless, further studies are required to elucidate the mechanisms responsible for the antiviral properties of SDM25N (a $\delta$-opioid receptor antagonist). SDM25N was extracted from a small molecule library and exhibited antiviral activity in Hela and BHK-21 cell lines, although not in $\mathrm{C6} / \mathrm{C} 36$ cell lines derived from the Aedes albopictus mosquito [59].

Similarly, NITD-618 has been identified as an NS4B inhibitor, selected from a library of almost 1.8 million small molecules, this compound was found to be active against the four DENV serotypes, but inactive against other RNA viruses, including two other flaviviruses like WNV and YFV [38].

\section{NS5 protein inhibitors}

As mentioned, the NS5 protein displays a fundamental activity for the development of the flavivirus replication cycle, making this protein an important therapeutic target $[3,38,40,60,61]$ that can be attacked to affect viral RNA production. The inhibitory compounds discussed ahead have been evaluated against the two activities of this viral protein.

\section{Methyltransferase domain inhibitors}

Reports exist on the use of sinefungin, a SAM (S-adenosyl-L-methionine) analogue, as a broad-spectrum DENV inhibitor, Wesselsbron, and WNV methyltransferases. Sinefungin contains a carbon and amine instead of the methylated sulfur present in SAM, and the amine imitates the charged sulfur. The ligand binds to the SAM site in a similar way as SAM, but does not undergo similar interactions with the protein; despite this, interaction assays with DENV MTase show that sinefungin affinity is six times greater than SAM affinity [61].

Furthermore, other DENV NS5 protein inhibitors have been identified, such as S-adenosyl homocysteine (SAH) and Compound 10 (as inhibitors of the methyltransferase active site), guanosine monophosphate (GMP), BG-323, and aurintricarboxylic acid (with binding sites to the guanosine triphosphate (GTP) pocket), and 4-HPR (fenretinide) and ivermectin with unknown binding sites $[38,61]$.
S-adenosyl homocysteine, compound 10, GMP, and sinefungin did not show good progress because these are non-cell-permeable compounds. On the other hand, no information is available regarding BG-323 and aurintricarboxylic acid; while 4-HPR has shown to be efficient in a mouse model lacking type I and II IFN receptors and ivermectin is undergoing phase II/III clinical trials [61].

Ribavirin, a synthetic guanosine analogue, has shown to inhibit dengue methyltransferase and hepatitis $C$ virus replication [51, 62].

An assay with Rhesus monkeys showed that monkeys treated with ribavirin, as well as those treated with the placebo, developed viremia, with a peak between days 3 and 9 post-infection. In addition, there were no significant differences in the time of infection onset, duration, or viremia level in the two groups evaluated. Thus, ribavirin resulted inefficient as a prophylactic drug for type1 dengue virus infection [63].

\section{RNA-dependent RNA polymerase domain inhibitors}

Flavivirus RdRp have been considered among the most interesting drug targets because viral polymerase activity is essential for replication and human host cells lack this enzyme $[8,64,65]$. RNA polymerase inhibitors are divided into two classes: nucleosides inhibitors (NI) and nonnucleosides inhibitors (NNI) $[8,17,38,53,61,66]$. Nucleoside analogues are generally converted into nucleosides by host cell kinases [8]. Recently, two NNI: $\mathrm{N}$-(4-hydroxyphenyl) retinamide and ivermectin have been identified in binding assays as compounds able to block NS5 [61].

Ivermectin has been reported as an inhibitor of importin $\alpha / \beta$ and, consequently, of the NS5 polymerase, given that the former is required for its activity. Prior treatment with ivermectin inhibits dengue virus infection in vero cells; additionally, pre-treatment with this compound has been found to strongly inhibit the nuclear localization of NS5 during DENV-1 and DENV-2 infection in BHK-21 or Huh-7 cells [56]. However, problems related to the toxicity of ivermectin may present significant hurdles for its potential use in anti-DENV therapy [61].

On the other hand, the viral polymerase inhibitor 7deaza-2'-C-methyladenosine (7DMA) was identified as a potent ZIKV inhibitor. A mouse model for ZIKV infections, which was validated for antiviral studies, demonstrated that 7DMA markedly delays virus-induced disease in this model [67].

Nucleotide/nucleoside analogues induce termination of the nucleic acid chain or act as natural substrates through competition due to their broad-spectrum antiviral activity, or can cause mutation by incorporation to a newly synthesized RNA chain $[8,42]$. Also, NNI allosterically bind to pockets and/or surface cavities, thus, blocking enzyme 
activity; this mechanism includes structural alteration of the polymerase to an inactive conformation, blocking the conformation required for elongation initiation or preventing polymerase elongation $[8,17]$.

To date, few molecules, like flavivirus RdRp NIs and GTP analogues 3'dGTP, ddGTP, 3'dioxolane 3'dGTP, and 2'-O-methyl GTP have shown low IC50 values in in vitro activity assays with DENV RdRp.

There is an alleged NNI, ammonium-21-tungsto-9antimoniate, also called HPA 23, which inhibits DENV2 RdRp; this NNI was proposed to inhibit the HIV reverse transcriptase through competition with the nucleic acid template, resulting in a non-allosteric-type inhibitor [8].

Moreover, NITD 008 (an adenosine nucleoside) [38, 68], NITD 203 (a related compound) [30], and balapiravir (RG1626) (a cytidine nucleoside) have been reported as RdRp domain inhibitors [38, 61]. Both NITD 008 and NITD 203 induced inhibition of the four DENV serotypes, as well as of YFV and WNV [30]. NITD 203 proved efficient in in vitro and in vivo studies against dengue; however, it did not satisfactorily achieve non-observable levels of adverse effects within 2 weeks in in vivo studies [68]. Additionally, in vitro studies showed that NITD 008 activation was less effective in dengue pre-infection, compared to other compounds, although preclinical studies have shown that this drug presents toxicity problems [61].

In addition, balapiravir does not show efficiency in phase II clinical studies, given that this drug, initially developed for hepatitis $C$ treatment, it failed to achieve efficacy in dengue patients [61].

In contrast, dengue virus polymerase enzymatic activity has been inhibited allosterically through blockage of the RNA tunnel by using $\mathrm{N}$-sulfonylanthranilic acid derivatives, considered desirable to develop antiviral compounds [17]. Furthermore, the activity of this enzyme has been inhibited by action of beta-d-2'-ethynyl-7deaza-adenosine triphosphate (2'E-7D-ATP) through competition with the natural nucleotide. This nucleoside analogue, initially developed for $\mathrm{HCV}$, displayed antidengue activity in cell culture and significantly reduced viremia in a mouse model with DENV; nevertheless, the catalytic incorporation efficiency of this molecule is tenfold less than that of adenosine triphosphate (ATP) [18, 64]. Similarly, a study on the functional analysis of two cavities of the flavivirus NS5 polymerase determined that the B cavity could be a target for drug design because amino acid residues Leu 328, Lys 330, Trp 859, and Ile 863 are essential for viral replication [5].

Additionally, various modified triphenylmethyl nucleosides have shown in vitro anti-YFV and anti-DENV activity, although the antiviral activity of several of these compounds (4b, 4c, and 5b) was weaker in DENV [23].

2,5'-bis-O-tritylated uridine has been identified as a flavivirus inhibitor, specifically for YFV, in addition to some synthetic nucleoside analogues with different tritium regioisomers, which have been evaluated to establish a structure-activity relation (SAR) [23]. The compound inhibited YFV and DENV replication in a low $\mu \mathrm{M}$ range, proving that it can potentially inhibit the $R d R p$ [64]. Other in vitro studies have reported the activity of 3,5'-bis-O-tritylated uridine analogues for DENV and YFV RNA polymerase inhibition [23, 25].

Recently, the characterization of a novel allosteric pocket at the interface of the thumb and palm subdomains of DENV RdRp has been reported. It is located near the priming loop (aa782-809) of the enzyme and is lined by highly conserved residues across DENV1-4, as well as in other flaviviruses, including ZIKV. Inhibitors generated by rational design potently inhibited DENV1-4 polymerase de novo initiation activities and virus replication in various cell types. They bind with strong affinity to recombinant apo-enzyme, as well as FL NS5 from DENV replicon cell lysates. Compound 29 was one of the most potent compounds in the series, and compounds 27 and 29 were inactive when tested with the WNV replicon cell-based assay [11].

\section{Inhibitors with non-specific action}

Lycorine, which has a reported antiviral activity, has been evaluated against a number of flaviviruses and has acted as a WNV, YFV and DENV-1 inhibitor [21,38], although it has no WNV protease, NTPase, MTase, or RdRp inhibitor activity. Therefore, its action is not addressed directly against the enzymatic functions of the viral proteins [21].

Assays with amodiaquine (an anti-malaria drug) have shown that this compound presents activity against DENV-2 and inhibits RNA replication and virus infectivity in BHK-21 cells; however, it has been determined that neither the protease nor the polymerase are probable targets of this compound [33].

The action of AS101 (a non-toxic immunomodulator) has also been evaluated, showing anti-WNV effects in in vitro and in vivo systems [69].

An adenosine analogue (7-deaza-2'-C-acetylene-adenosine) has functioned as a potential inhibitor of DENV replication in cell culture and in a mouse model; however, this compound has shown serious effects in in vivo toxicity studies on rats and dogs [64].

In addition, DENV and YFV inhibition has been reported for derivatives of imidazole 4,5 dicarboxamide (I45DC), and pyrazine 2,3 dicarboxamide (P23DCs) [70].

Favipiravir, T-705, a pyrazine-substitute compound used in clinical trials to treat human influenza virus infections [64], inhibits various viral pathogens, including YFV and WNV, although greater concentrations are required for the latter two viruses in in vitro assays and 
in rodents, compared to influenza virus. It is worth noting that no envelope protein was reportedly found in WNV in treated animals 7 days after virus exposure; furthermore, oral administration of favipiravir in hamsters infected with YFV, starting four hours prior to virus exposure, protected the animals from death [71]. T-705 has also significantly improved survival and disease parameters in YFV-infected hamsters, despite the fact that this compound lacks good activity in in vitro assays [64].

Further studies are needed to evaluate T-705 as an antiviral treatment for WNV, given that it is one of the few known compounds that reduce mortality by WNV in rodents [72].

Studies on the action mechanism of T-705 have shown that the compound is converted into a triphosphate ribofuranosyl derivative by host enzymes and that it selectively inhibits the influenza virus RNA-dependent RNA polymerase, with no toxicity in mammal cells [72].

Furthermore, T-705, T-1105, and T-1106 derivatives can be considered candidates because these have shown good activity in treatments in laboratory animals infected with RNA viruses, including WNV and YFV. T1106 showed surprising therapeutic efficacy in a hamster model of YFV In any case, it is expected that T-1106 will be a useful drug for YF in humans [72].

On the other hand, it has been indicated that NITD008 (an adenosine analog) is an effective antiviral compound that protects mice from lethal ZIKV challenge. This study demonstrates that the A129 mouse model could be used for testing the in vivo efficacy of ZIKV inhibitors [27, 43, 73].

Also, has been report the susceptibility of Zika virus envelope protein (ZVEP) to inhibition via two small molecules, ZINC33683341 and ZINC49605556 by preferentially binding onto the primary receptor responsable for the virus' virulence. Antiviral activity was confirmed when ZINC33683341 was tested in cell culture [74].

\section{Conclusions}

Flaviviruses cause some of the most important diseases among emerging diseases, leading to a much-needed constant search for inhibitory compounds, given that only a few of these viruses currently have an approved vaccine, while others remain under evaluation in the search for substrates that affect the viral replication process, because until now no antiviral compounds have been approved to treat diseases caused by flaviviruses. Due to their endemic nature, JEV, WNV, DENV, FEV, TEBV and ZIKV are among the viruses of greatest interest $[3,6]$. NS3 and NS5 are among the most important protein targets because they carry out enzymatic functions of high interest $[3,38]$ and are part of the replication complex, along with viral RNA, viral cofactors and host cell cofactors [37], making them attractive inhibitor targets [31, 37, 40].

Aprotinin and anthracene-based compounds are among the molecules used to affect DENV NS3 protein activity by affecting the protease domain [53], in addition to ivermectin, suramin, and pyrrolone, among others, with action on the helicase domain [55-57]. As for the RdRp, an important role is played by nucleoside and non-nucleoside-type inhibitors, including GTP and adenosine analogues (NITD 008 and NITD 203) [30], and 2'E-7D-ATP [18, 64], as well as other molecules that induce DENV inhibition by allosteric coupling.

This review emphasized the different inhibitor compounds evaluated to affect replication of flaviviruses related to the most endemic diseases, like DENV, providing a broader vision of the types of molecules tested to date and of others that could be evaluated to achieve the final objective of many researchers throughout the world interested in studying flaviviruses: to find one or more compounds with the possibility of being vaccine candidates or that can be used as treatments for diverse effects produced by the presence of these viruses in the organism.

\begin{abstract}
Abbreviations
2'E-7D-ATP: Beta-d-2'-ethynyl-7-deaza-adenosine triphosphate; ATP: Adenosine triphosphate; BHK-21: Baby Hamster Kidney fibroblasts; C: Capsid protein; CYD-TDV: Tetravalent Dengue Vaccine; DENV: Dengue virus; E: Envelope protein; EC50: Half-maximal effective concentration; GMP: Guanosine monophosphate; GTP: Guanosine triphosphate; HCV: Hepatitis C virus; HTS: High-throughput screening; JEV: Japanese Encephalitis Virus; M: Membrane protein; Mtase: Methyltransferase; NC: Nucleocapsid; NI: Nucleosides inhibitors; NITD: Novartis Institute for Tropical Diseases; NNI: Non-nucleosides inhibitors; NS: Nonstructural proteins; PFU: Plaqueforming unit; prM: Membrane protein precursor; RdRp: RNA-dependent RNA polymerase; SAH: S-adenosyl homocysteine; SAM: S-adenosyl methyltransferase; TBEV: Tick-Borne Encephalitis Virus; VCD: Virologically confirmed dengue; WNV: West Nile virus; YFV: Yellow fever virus; ZIKV: Zika virus
\end{abstract}

\section{Acknowledgements}

The authors thank the Group of Molecular Immunology at Universidad del Quindío and project of Colciencias code 1113-56933424.

Funding

Not applicable for that section.

Availability of data and materials

Not applicable for that section.

\section{Authors' contributions}

LG was the primary author of this manuscript and wrote the first drafts the sections. LP contributed the review the manuscript and assisted in drafting the manuscript. JC contributed in drafting the manuscript and assisted the construction of table. All authors have read and approved the final manuscript.

\section{Competing interests}

The authors declare that they have no competing interests.

\section{Consent for publication}

Not applicable for that section.

Ethics approval and consent to participate

Not applicable for that section. 


\section{Publisher's Note}

Springer Nature remains neutral with regard to jurisdictional claims in published maps and institutional affiliations.

Received: 2 December 2016 Accepted: 2 May 2017

Published online: 15 May 2017

\section{References}

1. Aubry F, Nougairède A, Gould EA, de Lamballerie X. Flavivirus reverse genetic systems, construction techniques and applications: a historical perspective. Antiviral Res. 2015;114:67-85.

2. Bollati M, Alvarez K, Assenberg R, Baronti C, Canard B, Cook S, Coutard B, Decroly E, de Lamballerie X, Gould EA, Grard G, Grimes JM, Hilgenfeld R, Jansson AM, Malet H, Mancini EJ, Mastrangelo E, Mattevi A, Milani M, Moureau G, Neyts J, Owens RJ, Ren J, Selisko B, Speroni S, Steuber H, Stuart DI, Unge T, Bolognesi M. Structure and functionality in flavivirus NS-proteins: perspectives for drug design. Antiviral Res. 2010;87:125-48.

3. Sampath A, Padmanabhan R. Molecular targets for flavivirus drug discovery. Antiviral Res. 2009;81:6-15.

4. Brault JB, Kudelko M, Vidalain PO, Tangy F, Desprès P, Pardigon N. The interaction of flavivirus $M$ protein with light chain Tctex-1 of human dynein plays a role in late stages of virus replication. Virology. 2011:417:369-78.

5. Zou G, Chen YL, Dong H, Lim CC, Yap L, Yau YH, Shochat SG, Lescar J, Shi PY. Functional analysis of two cavities in flavivirus NS5 polymerase. J Biol Chem. 2011;286:14362-72.

6. Giri R, Kumar D, Sharma N, Uversky VN. Intrinsically Disordered Side of the Zika Virus Proteome. Front Cell Infect Microbiol. 2016;6:144.

7. Potisopon S, Ferron F, Fattorini V, Selisko B, Canard B. Substrate selectivity of Dengue and Zika virus NS5 polymerase towards 2'-modified nucleotide analogues. Antiviral Res. 2017;140:25-36.

8. Malet H, Massé N, Selisko B, Romette JL, Alvarez K, Guillemot JC, Tolou H, Yap TL, Vasudevan S, Lescar J, Canard B. The flavivirus polymerase as a target for drug discovery. Antiviral Res. 2008;80:23-35.

9. Villar L, Dayan GH, Arredondo-García JL, Rivera DM, Cunha R, Deseda C, Reynales H, Costa MS, Morales-Ramírez JO, Carrasquilla G, Rey LC, Dietze R, Luz K, Rivas E, Miranda Montoya MC, Cortés Supelano M, Zambrano B, Langevin E, Boaz M, Tornieporth N, Saville M, Noriega F F, CYD15 Study Group. Efficacy of a tetravalent dengue vaccine in children in Latin America. N Engl J Med. 2015;372:113-23.

10. Lai JH, Lin YL, Hsieh SL. Pharmacological intervention for dengue virus infection. Biochem Pharmacol. 2017;129:14-25.

11. Lim SP, Noble CG, Seh CC, Soh TS, El Sahili A, Chan GK, Lescar J, Arora R, Benson T, Nilar S, Manjunatha U, Wan KF, Dong H, Xie X, Shi PY, Yokokawa F. Potent Allosteric Dengue Virus NS5 Polymerase Inhibitors: Mechanism of Action and Resistance Profiling. Plos Pathog. 2016;12(8):e1005737.

12. Vasudevan SG, Johansson M, Brooks AJ, Llewellyn LE, Jans DA. Characterisation of inter- and intra-molecular interactions of the dengue virus RNA dependent RNA polymerase as potential drug targets. Farmaco. 2001;56:33-6.

13. Padmanabhan R, Pattabiraman N, Mueller N, Nagarajan K, inventors; Georgetown University, assignee. Flavivirus inhibitors and methods for their use. United States patent US8563580 B2. 2013 Oct 22.

14. Padmanabhan $\mathrm{R}$, Teramoto T, Manzano M, inventors; inventors; Georgetown University, assignee. Flavivirus protease inhibitors. United States patent US20150272976 A1. 2015 Oct 01.

15. Garry R, Dash S, Coy D, McKeating J, inventors; The Administrators Of The Tulane Educational Fund, The Rockefeller University, assignee. Flavivirus fusion inhibitors. United States patent US7416733 B2. 2008 Ago 26.

16. Li J, Harris J, Tumanut C, inventors; Irm LIC, A Delaware Limited Liability Company, assignee. Flavivirus protease substrates and inhibitors. United States patent US20080032917 A1. 2008 Feb 07.

17. Niyomrattanakit $P$, Chen YL, Dong H, Yin Z, Qing M, Glickman JF, Lin K, Mueller D, Voshol H, Lim JY, Nilar S, Keller TH, Shi PY. Inhibition of dengue virus polymerase by blocking of the RNA tunnel. J Virol. 2010;84:5678-86.

18. Latour DR, Jekle A, Javanbakht H, Henningsen $R$, Gee P, Lee I, Tran P, Ren S, Kutach AK, Harris SF, Wang SM, Lok SJ, Shaw D, Li J, Heilek G, Klumpp K, Swinney DC, Deval J. Biochemical characterization of the inhibition of the dengue virus RNA polymerase by beta-d-2'-ethynyl-7-deaza-adenosine triphosphate. Antiviral Res. 2010:87:213-22.

19. Padilla-S L, Rodríguez A, Gonzales MM, Gallego-G JC, Castaño-O JC. Inhibitory effects of curcumin on dengue virus type 2-infected cells in vitro. Arch Virol. 2014;159:573-9.
20. Dong H, Zhang B, Shi PY. Flavivirus methyltransferase: a novel antiviral target. Antiviral Res. 2008:80:1-10.

21. Zou G, Puig-Basagoiti F, Zhang B, Qing M, Chen L, Pankiewicz KW, Felczak K, Yuan Z, Shi PY. A single-amino acid substitution in West Nile virus $2 \mathrm{~K}$ peptide between NS4A and NS4B confers resistance to lycorine, a flavivirus inhibitor. Virology. 2009:384:242-52.

22. Heinz FX, Stiasny K. Flaviviruses and flavivirus vaccines. Vaccine. 2012;30: 4301-6.

23. Chatelain G, Debing Y, De Burghgraeve T, Zmurko J, Saudi M, Rozenski J, Neyts J, Van Aerschot A. In search of flavivirus inhibitors: evaluation of different tritylated nucleoside analogues. Eur J Med Chem. 2013;65:249-55.

24. Nazmi A, Dutta K, Hazra B, Basu A. Role of pattern recognition receptors in flavivirus infections. Virus Res. 2014;185:32-40.

25. Saudi M, Zmurko J, Kaptein S, Rozenski J, Neyts J, Van Aerschot A. In search of flavivirus inhibitors part 2: tritylated, diphenylmethylated and other alkylated nucleoside analogues. Eur J Med Chem. 2014a;76:98-109.

26. Klema VJ, Ye M, Hindupur A, Teramoto T, Gottipati K, Padmanabhan R, Choi $\mathrm{KH}$. Dengue Virus Nonstructural Protein 5 (NS5) Assembles into a Dimer with a Unique Methyltransferase and Polymerase Interface. Plos Pathog. 2016;12(2):e1005451.

27. Adcock RS, Chu YK, Golden JE, Chung DH. Evaluation of anti-Zika virus activities of broad-spectrum antivirals and $\mathrm{NIH}$ clinical collection compounds using a cell-based, high-throughput screen assay. Antiviral Res. 2017;138:47-56

28. Villordo SM, Gamarnik AV. Genome cyclization as strategy for flavivirus RNA replication. Virus Res. 2009;139:230-9.

29. Pastorino B, Nougairède A, Wurtz N, Gould E, de Lamballerie X. Role of host cell factors in flavivirus infection: Implications for pathogenesis and development of antiviral drugs. Antiviral Res. 2010;87:281-94.

30. Caillet-Saguy C, Lim SP, Shi PY, Lescar J, Bressanelli S. Polymerases of hepatitis C viruses and flaviviruses: structural and mechanistic insights and drug development. Antiviral Res. 2014;105:8-16.

31. Apte SS, Sirohi D, Kuhn RJ. Coupling of replication and assembly in flaviviruses. Curr Opin Virol. 2014:9:134-42.

32. Lescar J, Luo D, Xu T, Sampath A, Lim SP, Canard B, Vasudevan SG. Towards the design of antiviral inhibitors against flaviviruses: the case for the multifunctional NS3 protein from Dengue virus as a target. Antiviral Res. 2008:80:94-101.

33. Boonyasuppayakorn S, Reichert ED, Manzano M, Nagarajan K, Padmanabhan R. Amodiaquine, an antimalarial drug, inhibits dengue virus type 2 replication and infectivity. Antiviral Res. 2014;106:125-34.

34. Perera R, Khaliq M, Kuhn RJ. Closing the door on flaviviruses: entry as a target for antiviral drug design. Antiviral Res. 2008;80:11-22.

35. Xie X, Zou J, Wang QY, Shi PY. Targeting dengue virus NS4B protein for drug discovery. Antiviral Res. 2015;118:39-45.

36. Muller DA, Young PR. The flavivirus NS1 protein molecular and structural biology, immunology, role in pathogenesis and application as a diagnostic biomarker. Antiviral Res. 2013;98:192-208.

37. Luo D, Vasudevan SG, Lescar J. The flavivirus NS2B-NS3 protease-helicase as a target for antiviral drug development. Antiviral Res. 2015;118:148-58.

38. Lim SP, Wang QY, Noble CG, Chen YL, Dong H, Zou B, Yokokawa F, Nilar S, Smith P, Beer D, Lescar J, Shi PY. Ten years of dengue drug discovery: progress and prospects. Antiviral Res. 2013a;100:500-19.

39. Yap TL, Xu T, Chen YL, Malet H, Egloff MP, Canard B, Vasudevan SG, Lescar J. Crystal structure of the dengue virus RNA-dependent RNA polymerase catalytic domain at 1.85-angstrom resolution. J Virol. 2007:81:4753-65.

40. Bhattacharya D, Hoover S, Falk SP, Weisblum B, Vestling M, Striker R. Phosphorylation of yellow fever virus NS5 alters methyltransferase activity. Virology. 2008;380:276-84.

41. Taylor RT, Best SM. Assessing ubiquitination of viral proteins: lessons from flavivirus NS5. Methods. 2011:55:166-71.

42. Najera I. Resistance to HCV nucleoside analogue inhibitors of hepatitis $C$ virus RNA-dependent RNA polymerase. Curr Opin Virol. 2013;3:508-13.

43. Xie X, Zou J, Shan C, Yang Y, Kum DB, Dallmeier K, Neyts J, Shi PY. Zika virus replicons for drug discovery. EBioMedicine. 2016;12:156-60.

44. Zhou Z, Khaliq M, Suk JE, Patkar C, Li L, Kuhn RJ, Post CB. Antiviral compounds discovered by virtual screening of small molecule libraries against dengue virus E protein. ACS Chem Biol. 2008:3:765-75.

45. Badani H, Garry RF, Wimley WC. Peptide entry inhibitors of enveloped viruses: the importance of interfacial hydrophobicity. Biochim Biophys Acta. 2014;1838(9):2180-97. 
46. Lok SM, Costin JM, Hrobowski YM, Hoffmann AR, Rowe DK, Kukkaro P, Holdaway H, Chipman P, Fontaine KA, Holbrook MR, Garry RF, Kostyuchenko V, Wimley WC, Isern S, Rossmann MG, Michael SF. Release of dengue virus genome induced by a peptide inhibitor. Plos One. 2012;7:5-12.

47. Byrd CM, Dai D, Grosenbach DW, Berhanu A, Jones KF, Cardwell KB, Schneider C, Wineinger KA, Page JM, Harver C, Stavale E, Tyavanagimatt S, Stone MA, Bartenschlager R, Scaturro P, Hruby DE, Jordan R. A nove inhibitor of dengue virus replication that targets the capsid protein. Antimicrob Agents Chemother. 2013;57:15-25

48. Yang CC, Hu HS, Wu RH, Wu SH, Lee SJ, Jiaang WT, Chern JH, Huang ZS, Wu HN, Chang CM, Yueh A. A novel dengue virus inhibitor, BP13944, discovered by highthroughput screening with dengue virus replicon cells selects for resistance in the viral NS2B/NS3 protease. Antimicrob Agents Chemother. 2014;58:110-9.

49. Steuer C, Gege C, Fischl W, Heinonen KH, Bartenschlager R, Klein CD. Synthesis and biological evaluation of a-ketoamides as inhibitors of the Dengue virus protease with antiviral activity in cell-culture. Bioorg Med Chem. 2011;19:4067-74.

50. Prusis $P$, Junaid M, Petrovska R, Yahorava S, Yahorau A, Katzenmeier G, Lapins M, Wikberg JE. Design and evaluation of substrate-based octapeptide and non substrate-based tetrapeptide inhibitors of dengue virus NS2B-NS3 proteases. Biochem Biophys Res Commun. 2013;434:767-72.

51. Tomlinson SM, Watowich SJ. Anthracene-based inhibitors of dengue virus NS2B-NS3 protease. Antiviral Res. 2011;89:127-35.

52. Chu JJ, Lee RC, Ang MJ, Wang WL, Lim HA, Wee JL, Joy J, Hill J, Brian Chia CS. Antiviral activities of 15 dengue NS2B-NS3 protease inhibitors using a human cell-based viral quantification assay. Antiviral Res. 2015;118:68-74.

53. Noble CG, Chen YL, Dong H, Gu F, Lim SP, Schul W, Wang QY, Shi PY. Strategies for development of dengue virus inhibitors. Antiviral Res. 2010;85:450-62.

54. Luo D, Xu T, Watson RP, Scherer-Becker D, Sampath A, Jahnke W, Yeong SS, Wang $\mathrm{CH}$, Lim SP, Strongin A, Vasudevan SG, Lescar J. Insights into RNA unwinding and ATP hydrolysis by the flavivirus NS3 protein. EMBO J. 2008;27:3209-19.

55. Mastrangelo E, Pezzullo M, De Burghgraeve T, Kaptein S, Pastorino B, Dallmeier K, de Lamballerie X, Neyts J, Hanson AM, Frick DN, Bolognesi M, Milani M. Ivermectin is a potent inhibitor of flavivirus replication specifically targeting NS3 helicase activity: new prospects for an old drug. J Antimicrob Chemother. 2012;67:1884-94

56. Tay MY, Fraser JE, Chan WK, Moreland NJ, Rathore AP, Wang C, Vasudevan SG, Jans DA. Nuclear localization of dengue virus (DENV) 1-4 non-structural protein 5; protection against all 4 DENV serotypes by the inhibitor Ivermectin. Antiviral Res. 2013;99:301-6.

57. Sweeney NL, Hanson AM, Mukherjee S, Ndjomou J, Geiss BJ, Steel JJ, Frankowski KJ, Li K, Schoenen FJ, Frick DN. Benzothiazole and Pyrrolone Flavivirus Inhibitors Targeting the Viral Helicase. ACS Infect Dis. 2015;1:140-8.

58. Basavannacharya C, Vasudevan SG. Suramin inhibits helicase activity of NS3 protein of dengue virus in a fluorescence-based high throughput assay format. Biochem Biophys Res Commun. 2014;453:539-44.

59. Van Cleef KW, Overheul GJ, Thomassen MC, Kaptein SJ, Davidson AD, Jacobs M, Neyts J, van Kuppeveld FJ, van Rij RP. Identification of a new dengue virus inhibitor that targets the viral NS4B protein and restricts genomic RNA replication. Antiviral Res. 2013;99:165-71.

60. Lim SP, Koh JH, Seh CC, Liew CW, Davidson AD, Chua LS, Chandrasekaran R, Cornvik TC, Shi PY, Lescar J. A crystal structure of the dengue virus nonstructural protein 5 (NS5) polymerase delineates interdomain amino acid residues that enhance its thermostability and de novo initiation activities. J Biol Chem. 2013b;288(43):31105-14.

61. Lim SP, Noble CG, Shi PY. The dengue virus NS5 protein as a target for drug discovery. Antiviral Res. 2015;119:57-67.

62. Chang J, Schul W, Butters TD, Yip A, Liu B, Goh A, Lakshminarayana SB, Alonzi D, Reinkensmeier G, Pan X, Qu X, Weidner JM, Wang L, Yu W, Borune N, Kinch MA, Rayahin JE, Moriarty R, Xu X, Shi PY, Guo JT, Block TM. Combination of a-glucosidase inhibitor and ribavirin for the treatment of dengue virus infection in vitro and in vivo. Antiviral Res. 2011;89:26-34.

63. Malinoski FJ, Hasty SE, Ussery MA, Dalrymple JM. Prophylactic ribavirin treatment of dengue type 1 infection in rhesus monkeys. Antiviral Res. 1990;13:139-49.

64. De Burghgraeve T, Selisko B, Kaptein S, Chatelain G, Leyssen P, Debing Y, Jacobs M, Van Aerschot A, Canard B, Neyts J. 3',5'Di-O-trityluridine inhibits in vitro flavivirus replication. Antiviral Res. 2013;98:242-7.

65. Meguellati A, Ahmed-Belkacem A, Yi W, Haudecoeur R, Crouillère M, Brillet R, Pawlotsky JM, Boumendjel A, Peuchmaur M. B-ring modified aurones as promising allosteric inhibitors of hepatitis C virus RNA-dependent RNA polymerase. Eur J Med Chem. 2014;80:579-92.
66. Betzi S, Eydoux C, Bussetta C, Blemont M, Leyssen P, Debarnot C, Ben-Rahou M, Haiech J, Hibert M, Gueritte F, Grierson DS, Romette JL, Guillemot JC, Neyts J, Alvarez K, Morelli X, Dutartre H, Canard B. Identification of allosteric inhibitors blocking the hepatitis C virus polymerase NS5B in the RNA synthesis initiation step. Antiviral Res. 2009;84:48-59.

67. Zmurko J, Marques RE, Schols D, Verbeken E, Kaptein SJ, Neyts J. The Viral Polymerase Inhibitor 7-Deaza-2'-C-Methyladenosine Is a Potent Inhibitor of In Vitro Zika Virus Replication and Delays Disease Progression in a Robust Mouse Infection Model. Plos Negl Trop Dis. 2016;10(5):e0004695.

68. Chen YL, Yin Z, Duraiswamy J, Schul W, Lim CC, Liu B, Xu HY, Qing M, Yip A Wang G, Chan WL, Tan HP, Lo M, Liung S, Kondreddi RR, Rao R, Gu H, He H, Keller TH, Shi PY. Inhibition of dengue virus RNA synthesis by an adenosine nucleoside. Antimicrob Agents Chemother. 2010;54:2932-9.

69. Indenbaum V, Bin H, Makarovsky D, Weil M, Shulman LM, Albeck M, Sredni $B$, Mendelson E. In vitro and in vivo activity of AS101 against West Nile virus WNV). Virus Res. 2012;166:68-76.

70. Saudi M, Zmurko J, Kaptein S, Rozenski J, Neyts J, Van Aerschot A. Synthesis and evaluation of imidazole-4,5- and pyrazine-2,3 dicarboxamides targeting dengue and yellow fever virus. Eur J Med Chem. 2014b;87:529-39.

71. Furuta Y, Gowen BB, Takahashi K, Shiraki K, Smee DF, Barnard DL. Favipiravir (T705), a novel viral RNA polymerase inhibitor. Antiviral Res. 2013;100:446-54.

72. Furuta Y, Takahashi K, Shiraki K, Sakamoto K, Smee DF, Barnard DL, Gowen BB, Julander JG, Morrey JD. T-705 (favipiravir) and related compounds: Novel broad-spectrum inhibitors of RNA viral infections. Antiviral Res. 2009:82:95-102.

73. Deng YQ, Zhang NN, Li CF, Tian M, Hao JN, Xie XP, Shi PY, Qin CF. Adenosine Analog NITD008 Is a Potent Inhibitor of Zika Virus. Open Forum Infect Dis. 2016;3(4):175.

74. Sandun F, Teshan F, Michal S, Ludek E, Ruzek D. An Approach for Zika Virus Inhibition Using Homology Structure of the Envelope Protein. Mol Biotechnol. 2016;58:801-6.

\section{Submit your next manuscript to BioMed Central and we will help you at every step:}

- We accept pre-submission inquiries

- Our selector tool helps you to find the most relevant journal

- We provide round the clock customer support

- Convenient online submission

- Thorough peer review

- Inclusion in PubMed and all major indexing services

- Maximum visibility for your research

Submit your manuscript at www.biomedcentral.com/submit
( ) BioMed Central 